\title{
Paradox, Incompleteness and Labyrinth in Fichte's Wissenschaftslehre
}

\section{Diogo Ferrer}

revues.org

Electronic version

URL: http://ref.revues.org/676

ISSN: 2258-014X

\section{Electronic reference}

Diogo Ferrer, «Paradox, Incompleteness and Labyrinth in Fichte's Wissenschaftslehre », Revista de Estud(i)os sobre Fichte [Online], 12 | 2016, Online since 01 December 2016, connection on 13 December 2016. URL : http://ref.revues.org/676

This text was automatically generated on 13 décembre 2016 .

(c) EuroPhilosophie
Publisher

EuroPhilosophie Editions 


\title{
Paradox, Incompleteness and Labyrinth in Fichte's Wissenschaftslehre
}

\author{
Diogo Ferrer
}

\section{On the form and development of the Science of Knowledge (WL)}

1 Although there are some similarities between the main divisions of Fichte's successive expositions of the WL, especially after 1805 , a common form or method is hardly to be found. We could compare the common character of the different versions of the WL to family resemblances, like a set of features which intersect, return and become recognized again under different guises, appearing without a necessary order or sequence. Fichte successively employs concepts such as "absolute I", "consciousness", "absolute knowing", "intellectual intuition", "existence", "image" or "appearance as appearance" to express the main principle of the WL, and such differences contribute to the changes in the forms of exposition.

2 The crisis in Fichte's thought that followed the charge of atheism at the turn of the $19^{\text {th }}$ century was caused, first, by the need, imposed on Fichte primarily by external factors, to clarify the role of the absolute in the WL, and secondly, by the pressure to produce an epistemological justification for his point of view. Both problems, namely the question regarding the role of the absolute, and the question regarding the epistemological justification of the WL, are met in the large propaedeutic and critical Introduction to the $\mathrm{WL}$ at the beginning of the Darstellung der Wissenschaftslehre (Exposition of the WL) from $1801 / 1802$. This Introduction is completely different from the $1^{\text {st }}$ and $2^{\text {nd }}$ Introductions of 1797, which take knowing (Wissen) as an object, and not as an act of the subject.

3 Following the charge of atheism and the criticism of the "point of view of reflection", which started around the same time, the problem of an epistemological justification of 
the WL began to be taken seriously by Fichte. The Introduction to the WL can no longer consist in simply bringing the reader into an external and alien object to be known, but it must reflect knowing in itself and construct a "knowing of knowing" "Wissen des Wissens ") or "absolute knowing", which does not admit a subject outside it. A significant innovation in the Exposition of the Wissenschaftslehre of 1801/1802 is thus the extensive propaedeutic and critical introduction which precedes the WL in the strict sense. This innovation is distinctive of the lectures on the WL from 1801/1802, and is not to be found in a similar way in any of the expositions in the following or in the preceding years. The reason for this exception is that, according to the new concepts and definitions of the later WL, the functions of a critical and propaedeutic introduction do not fit into a previous and separate place, but can and should be included in the body of the WL. The so-called "Wahrheitslehre" ("Doctrine of Truth") of the second exposition in 1804, for example, is in some of its functions comparable to the Introduction of $1801 / 1802$, but it is conceptually part of the WL, and not just a preliminary to it. The result of including propaedeutic and critique in the theory itself is the illumination of some inner tensions of the WL, which will be essential in its late presentations, as I will discuss later.

The changes in the external form of the WL, such as the addition of an Introduction and large divisions of the text, are much greater before 1804 or 1805 than after. Notwithstanding significant internal differences in the way of exposition and argumentation, the external form is relatively stable after 1805 . This stability occurs by virtue of the assimilation into the WL of the above mentioned features, including the selfjustification of its own procedures and, also, a transcendental-critical approach to the problem of the absolute and ultimate foundations. These are no longer treated as matters to be solved prior the presentation of the WL itself but as the core theoretical elements in it. This relatively stable external form comprises too many points of departure, contents and concepts to be studied in detail here. Therefore, I will restrict my focus to some difficult points which seems to me especially important for interpreting Fichte's WL in its different expositions and in its development.

\section{On the role of oppositions in the WL}

5 As a result of those developments, the WL becomes, on the one hand, a theory constantly examining its own epistemological conditions. At every step it calls into question how its own statements and concepts can be thought or realized. On the other hand, as a consequence of this, the WL "oscillates" ("wavers": "schwebt") between idealism and realism, problematic and categorical - according to the well-known expression "wenn... soll.../so...muss..." ("if it should.../then it must...") - between intuition and understanding, consciousness and self-consciousness, WL and actual knowing, amongst others. The point is now to show the impossibility of thinking one term of these oscillating pairs without the other. The general unifying term of the disjunction is the concept Fichte calls "light" and which he defines as "pure genesis". "Light" is accordingly often characterized as "absolute sequence" or "absolute relation", which means insight into the unity of the two terms. But because Fichte also tries to show that pure "light" cannot be thought without generating its opposite, the content of the system is essentially unstable, and its epistemological clarification always involves a game of mutual eclipses and mutual interference of its terms. 
6 It could be useful to distinguish this way of thinking from Hegel's dialectics. The latter produces synthetic concepts which preserve and subordinate the opposites, solving the contradiction in a greater concreteness, while in the WL the opposition is not strictly speaking resolved in a synthetic concept, but suspended or extended as an infinite function of knowing. This extension results from the "annihilation" or negation of the concept and the production of the differences that define reflection, intuition and image. Fichte names this absence of an immediate resolution of the oppositions and mutual eclipse of the different insights the "irrational hiatus", "facticity" or "problematic form" ("Problematizität") which affects the results of the WL, with the exception of the demonstration of this very problematic form. This is indeed apodictic. Since it is problematic, the WL's methodology is grounded on a "Sollen" ("should") which is neither necessary nor contingent, but an object of free choice. In 1804, for example, "we appear to ourselves as a mere task, that may be fulfilled or not, that wavers regarding its actuality between being and not-being [...]." In its full development this thesis finally becomes the impossibility of thinking the "problematic form" ("Problematizitat") without the "categorical form" ("Kategorizität"), and conversely, so that one cannot decide whether the ground of the WL is categorical or problematic. ${ }^{2}$

7 But Fichte does not interpret this situation of epistemological pessimism, which finds the apodictic form only at a meta-level of reflection, as an insufficiency or as an unsolvable epistemological problem. The WL, so to say, fills in this insufficiency with content, insofar as it makes it the transcendental condition of consciousness. Hence, the WL will try to show that the mutual implication of the opposites is the necessary condition of human knowing and consciousness.

\section{Some principles for the interpretations of Fichte's thought}

8 The oscillation, which is normally antinomic - the oscillating between realism and idealism where each term generates the other - is closely linked with the production of differences, the understanding of which seems to me essential for interpreting Fichte's text. Fichte's argumentative thread presupposes some main theoretical differences, which cannot be reduced to unity without cancelling the conditions of possible experience and consciousness. Much of the argumentation in the various versions of the WL is grounded on demonstrating the impossibility of annulling these differences, sometimes by reductio ad absurdum.

Thus, it is often asked what would happen if we were unable to distinguish the statement or the thought of something "in-itself" ("an sich") and the transcendental conditions that allow this thought, i.e., the form that the "In-itself" necessarily takes so that it can be thematic. It is also asked what it would be to know without the difference or distance between me and myself that seems to occur in all cases of the conscious reflection which, apparently, "must possibly accompany all my representations." ${ }^{3}$ But it should also be asked, finally, what it would mean for us to be unable to distinguish an immediate or intuitive level of consciousness from another one that is conceptual and discursive either by trying to account for knowing exclusively on the basis of concept alone, or from intuition alone. It can be concluded that any such attempt is based on self-oblivion, lack of reflection and half-philosophies affected by various kinds of blindness. 

the vocabulary of the WL, transcendental, reflective and critical difference. The first one, transcendental difference, makes it possible to produce the very object of the WL. As Fichte sometimes says, in order to acquire the object of the WL you must have the "transcendental spirit". Without this "spirit" the discourse will remain empty, because "where you speak, you speak about something that, in all other cases, is known and exists before this speaking of it: - here, you speak about something that is and becomes only by way of speaking about it." "Transcendental spirit" establishes the field of the WL, the reflective domain of the conditions of possibility of experience as distinct from the objects of experience. Every thematic object in the WL is defined on the basis of this difference, and its oblivion would mean that the WL is meaningless, because it would be empty.

11 The origin of this difference, as Fichte often stresses, is in close relation with the faculty of reflection, and the use of reflection as the main tool of philosophical thought. The second difference addressed by Fichte is, thus, the difference generated by the I, which finds herself only on the condition of distinguishing herself from herself. The statement "I am I" therefore presupposes identity but also non-identity. The place of the Not-I is, thence, foreseen already in the absolute I itself - if it should be an I at all - a question to which I will return further below. This function of the non-identical is essential for the structure of the WL, as it becomes clear, for instance, in the Grundlage der gesamten Wissenschaftslehre (Foundations of the Entire Science of Knowledge) of 1794/1795, where the argument appeals to the definition of "concept of the I" as necessarily reflecting on itself: "the I must reflect about itself." ${ }^{5}$ Or, to take another example, it is essential for the 1805 argument about the absolute light's untenability: "absolute light \{inwardly\} (i.e., which for its being does not presuppose anything but its own being), sees necessarily itself: a|a." ${ }^{6}$ The downfall of this difference, the pure I or pure light, which is beyond the statement of its own identity $(\mathrm{a} \mid \mathrm{a})$ would understand the absolute I as a pure expansion, or pure "genesis", that could not be objectified. Pure genesis, pure potentiality (faculty, " Vermögen"), from 1807 on, must interrupt or fix itself in order to make self-consciousness and reflection possible. Also the "image" is the key-concept of the late WL precisely because the image is meaningless without the recognition of the non-identity, as the absence of its object. The reflective difference is, finally, the reason why the image can only be image "as" ("als, "qua") such. The whole of the late WL, which begins with the notion of pure appearing ("Erscheinen") that knows itself as appearing ("als Erscheinung"), is therefore based on the reflective difference.

But this second form of difference is articulated also with the third one, namely, critical difference. This one is received directly from Kant, as the difference between intuition and concept. It is closely linked to reflection, since it is carried out by the understanding upon immediate intuition. The reflective difference could be systematically seen as the difference between the first act of pure genesis, the pure "springing up" ("Entspringen") and its reflective apprehension, which hinges on the conceptual faculty, intelligence or understanding. Fichte's position regarding the critical division and radical heterogeneity of the faculties, is to accept - contrarily to Kant - intellectual intuition but, as it is well known, as an "intuition of an act, not of any object." Intellectual intuition is a condition at the transcendental level of the faculties of experience's constitution, that confirms precisely the necessity of the split between intuition and understanding as condition of possibility for consciousness.

Revista de Estud(i)os sobre Fichte, 12| 0000 
13 Fichte articulates those three forms of difference in various arguments, establishing equivalences and systematically drawing conclusions. Those interpretation principles can be applied to formulations that expresses paradoxes, incompleteness and labyrinth in the $\mathrm{WL}$, as we shall see.

\section{Paradoxes, circularity and ambiguity} space, and which, as in a labyrinth, systematically oscillates between different directions until a central point is reached, from which it returns toward the surface. This is clearly the case of the antinomic wavering discussed in the second exposition of 1804, where the transcendental space is systematically and thoroughly fathomed until the definition of the "Ansich" ("In-itself") in the absolute sense, wherefrom the thought returns again. In this oscillation between idealism and realism, the energy of thought is the condition of possibility for representing its object. The object, in turn, conditions its representation, as object in itself. Expressed in another image, not exactly as a labyrinth, but as a circle, the field of transcendental philosophy is already in 1794/1795 described as an alternation where the thing in itself and the phenomenon reciprocally posit one another. This is "that circle which it [sc. the finite spirit] is able to extend into infinity, but can never scape."

15 I would like to show that these tropoi of paradoxes, circularities, or infinities are not merely formal but settle the conceptual content and conclusions of the $\mathrm{WL}$, according to at least some of its various versions. An analysis of Fichte's arguments and concepts, centered in some paradoxical, labyrinthine or else ambiguous cases allows one to read the $\mathrm{WL}$, in some of its different expositions, as a systematic production of incompleteness.

\subsection{Untying the conceptual knot}

The first passage in the text to which I would like to call your attention is a key passage in the Foundations of the Wissenschaftslehre where Fichte presents a main discovery which emerges in the course of the first exposition of the WL. Fichte seems to discover that the exposition actually carried out, where the first principles are presented in an independent way, is inadequate, and even appears to be contradictory. It is this inadequacy and apparent contradiction that Fichte attempts to solve in the following expositions, without essentially changing his main theses. In some way, therefore, the Foundations of 1794/1795 work toward their own invalidation, or toward showing that its own exposition is untenable. More specifically, Fichte intends to show that the unification of I and Not-I is ultimately not possible under the presupposed conditions, i.e., by presenting the principles as unconditioned acts of human spirit understood as three absolutes without a reciprocal relation.

17

As noted already by an early interpreter, M. Wundt, ${ }^{10}$ the Foundations of 1794/1795 display strong tensions, where the contradiction is not resolved, and a "tragic" mode of philosophy is carried out, which stresses the inadequacy of the sensible to the intelligible. But this only happens because the verification of a deadlock, and the impossibility of proceeding further is required in order to solve the problem of the system of knowing. 
Fichte speaks thus of a "knot [that] is not so much loosed as projected into infinity." Untying the knot is thus presented as an infinite process.

Notwithstanding the greater or lesser adequacy of the external form of exposition, it should be noted that it is this very impossibility of solving the problem that is raised into a system. In fact, regarding the aforesaid knot, the philosopher states that "we do not so much explain the explicandum as show rather, that, and why, it is inexplicable." ${ }^{12}$ At several key points in the lectures on the WL, the issue is to find the deadlocks, which are sometimes expressed as paradoxes, and to draw systematic conclusions from them. It is the exposition of deadlocks and aporiai that causes a change in point of view, that makes it possible to apprehend the $\mathrm{WL}$, or even to enter into it, according to some of its versions.

Later in the Foundations of 1794/1795, Fichte states: "we can see [...] how the very circumstance which threatened to destroy the possibility of a theory of human cognition becomes the sole condition under which such a theory can be established." ${ }^{13}$ This passage reveals an important feature of the WL as a reinterpretation of Kant's transcendentalism. This feature, which I will address now, can be found in different concepts with distinct roles in the various versions of the WL. These concepts express synthetic solutions for the problem of oppositions which seems to be irreducible: in the Foundations, the "imagination", later, the concept of "image". Other concepts sometimes play a similar role, in a somewhat negative stage, i.e., they express that "circumstance which threatened to destroy the possibility of a theory of human cognition", namely the concepts of "irrational hiatus", "fact" or "facticity".

The aforementioned threatening circumstance is the incompatibility between the absolute opposing concepts which, at the point of the Foundations quoted, are the "finite subjective and the infinite objective." ${ }^{14}$ But the problem has no solution insofar as it is posited at the level of what is "merely [...] thought." ${ }^{15}$ The answer therefore will not be to give up the construction of a system of knowing, but to change the way of thinking. Thought must be extended beyond itself, which is done by the faculty of transcendental imagination and intuition. This space -literally outside thought- produces the schematism of empirical reality, insofar as it allows one to think the opposites together, without reducing them to nothing. The sharp conceptual opposites are potentialized and posited by the imagination in simple spatial and temporal extension.

Fichte's thesis is that the impossibility of proceeding further does not prove that the project of a systematic foundation of knowing is impossible, but it shows, on the contrary, the necessity of facticity, of the hiatus or, finally, of experience as conditions of possibility for the system. Experience is the expression of the contradictory nature of concept in itself, and it is, thus, possible to demonstrate a priori the fact that experience is not a priori deductible.

Imagination is the non-conceptual production of reality, it constitutes the "state of intuition", which links thought to "touching" (Berühren) ${ }^{16}$ and to "reality", considering that Fichte accepts the empiricist thesis that "there is no other reality save that derived through intuition." ${ }^{17}$ This reality function will appear again under the form of "existence" ("Dasein") in the later versions of the WL. 


\subsection{Experience as unaccomplished knowing} explained in a passage which expresses not so much a paradox, as an ambiguity that lies in the absolute I from the beginning and that makes itself increasingly explicit throughout the exposition. At first sight, one would say the whole exposition disallows itself with the conclusion that "if the Not-I is to be able to posit anything at all in the I, the condition for the possibility of such an alien influence must be grounded beforehand, prior to any effect from without, in the I as such, in the absolute I; the I must originally and absolutely posit in itself the possibility of something operating upon it; without detriment to its absolute positing of itself, it must leave itself open, as it were, to some other positing." ${ }^{21}$ We should especially note that the conclusion refers to the absolute I, and not to the finite or divisible I which, contrarily to the absolute I, is explicitly understood as open to determination by the Not-I. Insofar as it refers to the absolute I, the proposition is 
paradoxical, for the absolute I's definition was precisely being unconditioned, not admitting any determination, which is now denied by having to keep itself open to a foreign determination.

Some of the conclusions to be drawn from this paradoxical formula have already been pointed out above. First, concerning the development of the WL, it shows that the exposition of the Foundations of 1794/1795 is not suitable; it works in a constant revision of its own starting point, which will eventually lead to totally different expositions. In the lectures after 1804, which explicitly "go beyond the I", the problems that were already present in the Foundations appear in an analyzed way, i.e. divided into clearly distinguished concepts. The reflection is understood as establishing by itself its difference regarding being, according to the formulae sequence used in 1805: "a", "ala" and "a|axb". It means, "a", seeing or I, must duplicate itself reflectively, "a|a", and this duplication is conditioned by the opposition or distinction regarding an absolute being, "alaxb". The reflection of existence upon itself can only be carried out if it separates itself from its other, absolute being. There is no reflection without opening to being.

Also, according to the theory of image, image is image for two reasons. First, it must reflect in itself, and so it is autonomous, self-sufficient and posited by itself - and that is why it is also seeing, light or absolute genesis and pure "Entspringen" ("springing up"). Image is not an effect or a consequence of its object, but must have spontaneity within itself. On the other hand, however, image is image because, seen from another side, it is not self-sufficient, but depends on being, otherwise it wouldn't distinguish itself from pure being, and would simply be identified with it. But what distinguishes image from being? Precisely its reflective faculty, the feature which Fichte stresses, i.e., being image "as image" ("als Bild"). If the image didn't recognize itself as image, it would obviously not carry out its figurative function, but would adhere completely to the continuity of being. Every figuration has as its condition "reflexibility" ("Reflexibilität"), and the resulting difference toward being.

Meanwhile, as has been said, the discovery of the opening in the absolute I - which will develop into the theory of existence and image - is, in the Foundations of 1794/1795, a consequence of a structural ambiguity in the absolute I. This ambiguity lies in its being simultaneously autonomous and reflective. The problem is that the absolute I, because it is an I, is implicitly reflective, and this condition cannot be explicit from the beginning. However, as reflective, it has already passed into the finite I. The absolute I is ambiguous because it must be a pure non- or still pre-reflective potentiality to reflection. On the one hand, it is an absolute pre-reflective positing, on the other hand (still being an I), it implies a positing of reflection.

31 The I, as Fichte will explicitly find out later, cannot be absolute without being reflective. Thence, in the theory of life that Fichte works out in the WL of Königsberg, the "absolute life" cannot be but "seeing", and "seeing" is necessarily "seeing itself", because the absolute positing cannot refer but to itself. On the other hand, the absolute I cannot be self-referent without ceasing to be absolute. The paradoxical statement of the absolute I's opening to some other positing and to the determination by something alien to it is only the unavoidable consequence of the duplicity which will eventually make the concept of the absolute I unsuitable.

Again, this ambiguity or paradox could lead us once again to dismiss the WL as untenable, or to say that its exposition is simply wrong. As seen, on the contrary, the ambiguity 
should be understood as the very condition of human knowing, which oscillates between reflexibility and absolute autonomy. Such oscillation is - according to the theory of transcendental imagination - the substratum of every knowing and figuration. The object of the WL is to prove that consciousness is only possible under this paradoxical, ambiguous condition or hiatus.

\subsection{On the construction of absolute knowing in 1801/1802}

The problem with the Foundations of the WL is that the aforementioned ambiguity is not brought to light from the beginning but, on the contrary, the thesis of the absolute position is presented in such a way that the reader is led to admit exactly the opposite, i.e., that the absolute I is absolutely unconditioned and cannot be eclipsed, interfered with or determined by any other positing. Insofar as this ambiguity is not clearly exposed, this insufficiency in the exposition should be taken as a reason for its evolution. The concept of absolute knowing, as present in the introduction to the WL of 1801 is still an attempt to state from the beginning this paradoxical constitution of human consciousness.

treating absolute knowing or, more clearly, the knowing of knowing theoretically, is the impossibility of objectifying it. We know it - thematically and reflectively - always from the outside, as a thematic object of knowing. Any reflective definition of knowing will leave aside the knowing that constitutes this very definition itself. This knowing at a superior level is defined as an act that is not contained in the definition, in the "was" ("what"), or as we could say, in the "ti esti" of knowing. This act is by definition, ultimately non-objectified and irreducible to any concept of knowing. Therefore, absolute knowing cannot be built as the object of another knowing about it, but only by assuming that it is required to presuppose in it a pre-reflective act, endowed with a nonintellectual, non-descriptive and also non-predicative component of knowing.

\section{description of the successive reflection levels of the objectified knowing would go on forever unless it is understood that knowing contains a pragmatic component, of absolute spontaneity, also of facticity or of an intuition irreducible to the concept, the "what" (" Was"). As a free self-positing, the act that cannot be objectified is the pure "genesis"22 of knowing. Absolute knowing, as built in the WL of 1801/1802 is mainly the methodological consciousness of this fact. \\ The non-predicative component is the intuition of an act, or intellectual intuition. The} This is therefore a genetic knowing and, in the author's words, "it contains in itself its origin." Absolute knowing is also defined as the "interiority of the origin," i.e., the knowing with the methodological consciousness that the principle of freedom, or absolute self-positing, is the condition for the construction of a knowing of knowing, that is to say, of the WL. The act in question is free because it cannot be objectified - in the sense of being determined by concepts of experience. And thus associating freedom with that which cannot be objectified under concepts, Fichte will argue throughout the lectures that every contingency, incompleteness, and non-conceptual aspect of experience, (i.e., critical difference in general, with the 'mixed' character of experience associated with it), is nothing but an expression of freedom. Among such non-conceptual features studied by Fichte are the directions in space, the multiplicity of the I in space

Revista de Estud(i)os sobre Fichte, 12| 0000 
and the sequence of time. This mixed character of experience is what Fichte calls formal freedom determined by absolute being.

It is so because the genetic feature of the knowing that knows itself as originating from a free act, or from a self-intuition that cannot be objectified, is also an oscillating 'to-bebetween', a "Schweben". As Fichte states, "the central point and specific focus of the absolute knowing is found. It does not lay in grasping itself as knowing (by formal freedom) nor in the annulation in absolute being, but simply between both; one is not possible without the other." ${ }^{23}$ Knowing "wavers thus between its being and not-being: as it must surely do, since it brings in itself, knowing it, its origin." ${ }^{24}$ Oscillating between being and not-being, as Fichte argues in this text, also defines freedom, selfconsciousness and experience - i.e., the empirical world, or space and time - and that is why the WL consists in proving the impossibility of thinking any one of these terms without the other two. There is no freedom without self-consciousness or without empirical world; there is no empirical world, time or space without freedom; there is no self-consciousness without empirical world and freedom. This is the unbreakable link between freedom, which is self-positing and therefore disposes of being and not-being, and the reflective self-consciousness. As a conclusion, there is no self-consciousness without an irreducible domain of facticity, contingence and the empiric element.

\subsection{Incompatibility of form and matter}

Because of the pragmatic and non-predicative component of the argument, paradoxical constructions and self-cancelling expressions necessarily play a key role in it - according to the oscillation pointed out in the last point. We will see now how this self-cancelling is a main device, which functions in the content and the form of exposition. The paradox is presented as the annulation of the form by the matter of the insight: 'the absolute 'what' [Was] of knowing [...], as 'what', must find itself, regardless all freedom, [...] it must be for itself. It should thus intuit itself in this absolute 'what'. Now, any intuition is freedom, just because it is. The form of this insight will be, therefore, annulated by its matter, it just disappears in itself by itself." ${ }^{25}$ The form of the proposition is annulated by its stuff, for the 'what' it is, defined as the "being of knowing", because it is a definition of it, would not admit reflection, that is, the construction of a knowing of knowing, if it should be taken objectively - so to say "regardless freedom", regardless of its originating act. The form of any expression of knowing, which is free reflection and self-intuition is, thence, annulated by its matter, the simple being of knowing. Fichte explains that this would be "a knowing without self-consciousness," ${ }^{26}$ namely without the methodological consciousness of its own conditions, a knowing without self-explanation, without WL. The presupposition is always that the reflective self-awareness is an act that cannot be objectified or defined in a 'what', in a being of knowing, in summa, that cannot be thought. The performative component cannot be structurally translated into a semantic one. That is why the WL, in 1807, will turn into a philosophy of life, with the idea that seeing is living and living is seeing.

Reflective consciousness is an act that idealizes the 'what', the 'ti esti', i.e., the being of knowing. Idealizing being, reflective consciousness introduces the question in general ${ }^{27}$ and introduces skepticism or the nothingness of beings as it is thought and defined. Any "Was" ('what') should have a "Weil" ('because'), which can only be given by an ultimate grounding. Without that, being is illusory and subject to critical and skeptical dissolution. 
If the content of knowing is being as being, fixed and steady, then reflection is banned. The form of the insight, freedom, is thus, annulated by its matter.

The question returns some pages bellow, ${ }^{28}$ where Fichte remarks that "necessity" is a link of knowing in itself, an "absolute thinking" that doesn't allow "mobility" "Beweglichkeit "), i.e., the logic of questioning, named the "Weil" ("because"). The "Was" is now the necessity, which contraposes the "mobility" belonging to intuition - that is, to the nonconceptual, which can be or not be, or is and is not, according to the classical definition of movement, and of time and space in the empirical world. "What is in the intuition is there simply because it is: thus, it is no more simply what it is. That's why this intuition could not intuit, why it could not occur in any knowing, but simply annulated its form by its matter." ${ }^{29}$ This means just that there cannot be any intuition without reflection. The intuition introduces always the "Weil", because it is the expression of freedom, of the free and reflective speech of questioning. Insofar as only freedom can give an absolute genesis, and only freedom can give the "Weil", the intuition belongs necessarily to such a mobility and genesis. Pure intuition could not occur in any knowing, because it dispenses with the "Was" and keeps being indefinable. Fichte understands in this way that the moving and instable form of the intuition of the object is annulated by its matter, i.e., by the need to confer a definable shape to it, and also to itself. According to Fichte in 1801/1802, knowing, - sc., experience - is thus freedom as determined by absolute being.

41 Fichte is simply saying that you cannot think pure being, any more than you can think pure freedom, and that knowing is just, transcendentally speaking, this very impossibility. Those are self-cancelling expressions and are thus impossible, pointing out the necessity of their overcoming. Such eclipses of the form of the expression by its stuff contributes negatively, in these lectures, to a demonstration of the oscillation of knowing. Knowing lies neither in the self-apprehension in and as the pure formal freedom, nor in its self-annulation in absolute being, and consequent loss of itself, but "between both" (" zwischen beiden"), in the "wavering" between them, ${ }^{30}$ the same solution for the paradoxes of impossibility we have encountered already in the lectures of 1794/1795.

Two other expressions for this mutual eclipse of the a priori components of knowing should be briefly remarked upon. The incompatibility of an insight's form and matter also defines the very predicative form of expression, insofar as saying "is" is to introduce something, some matter, into visibility - and hence the "is" is defined also as "light" - as well as into discursivity, that is, the "is" gives the conceptual-judicative form. It is the very act of visibility, the "is", which is unutterable (it belongs to what cannot be said, but only shown...). It is not possible to express under the strict propositional form the transcendental difference, i.e., the statement of the light which allows seeing, because the propositional order occurs already inside the domain defined by the copula. Saying it would imply bringing the copula into the predicate, reflecting again and making the copula, which is form, content. The consequences are very clear to Fichte. As you can read in 1805, when you say that "knowing in itself is this or that, this latter knowing is surely also again a knowing," ${ }^{31}$ that would not be comprehended in the predicate, and would, so to say, be projected into an exteriority, in two possible ways: so that the definition of knowing be accepted, either the act of the subject must be forgotten; or there would be an infinite iteration. Fichte's strategy consists in understanding this addition to the objectified knowing as a principle of facticity, or as inalienable life. 's repeated invitation, at the beginning of some courses, simply to think pure being. This 
yields the evident contradiction that the thought of being is outside it and, henceforth, has no place in it, and is nothing at all. This difficulty results in the above mentioned concept of image as "being outside being." Actually, this is a figure equivalent to absolute knowing, whose construction requires a position at the same time outside knowing but still in some way belonging to it. Thinking the absolute as Schelling and Hegel claimed is an impossible task. In terms of an intentio recta, as Schelling proposed and as Kant had already shown, thought entangles itself into insoluble contradictions. Yet, as we know, such difficulties and contradictions won't result in an impossibility, but rather in the necessary incompleteness of the task.

\subsection{The form of the highest insight}

Since I must approach the conclusion, a reference should still be made to a statement in the WL of 1805, which expresses in quite a different way the difficulties already exposed. In some ways, it summarizes the problem and the solution proposed by the philosopher: "The ancient philosophers grasped thus very accurately the form of the highest and absolute insight. The mistake was only that they wanted to realize it. [...] Such insight is contradictory in itself; for insight posits the objectivity of the terms and, furthermore, two terms; while God's interior essence is immanence and unity. [...] (Besides, the possibility of consciousness is grounded on the impossibility of this proof.)" ${ }^{32}$ Referring to the ontological proof, this passage does not appear to express any paradox, but it is quite explicit about the condition of human consciousness that generates the paradoxes. According to Fichte, only a consciousness to which the ontological proof would be valid would be free from paradoxes.

On this point, we don't see any major differences from 1794 until 1805. The late WL accepts, as you can read in the quoted passage, the impossibility of "realizing" the supreme insight, that consists in passing from the absolute, as pure essence, to its existence. In fact, the principle of the whole exposition of 1805 is that "knowing is the existence of the absolute," but this link between the absolute and its existence cannot be an object of proof. In the markedly theologically minded version of 1807 , Fichte says that "God only reveals itself as the one who never reveals itself. [...] If he could ever enter entirely as it is into the phenomena, they would be over. It is only God's immediate drive, which will never be realized, to be the root of our apparent existence, that guarantees the infinity of this apparent existence of ours." "33 "To realize" hence means to make actual, as accomplishing, to turn into res, i.e., the referred objectifying of the terms inside the necessity of a concept. The ontological proof, which would allow one to think the concept of the absolute as comprehending existence, and as separated from any experience, projects a duality that Fichte rejects.

The impossibility of realizing the passage from the absolute to knowing, or the nondemonstrability that the absolute exists in knowing, insofar as existence is interrupted by an ultimate facticity, is also stressed by Fichte saying that "as existing, the absolute changes absolute and hopelessly its own inner essence. ${ }^{{ }^{34}}$ It is not the absolute that exists, or, if it exists, then it cannot exist as absolute - or, paradoxically, it can only exist as absolute. But the "as" makes all the difference, because it is the free principle of reflection and image, that may or may not posit itself. That is why Fichte says, in his later lectures, that the absolute's first scheme is a "Vermögen" ("faculty", "potentiality"). ${ }^{35}$ " 
Vermögen" is like a point, that may or may not actualize, may or may not extend into a line, acquire dimension necessarily and some direction freely.

The realization of the ontological proof is hindered by the very form of human reason, which, under the factual conditions of consciousness, does not allow deducing intuition and existence from any concept of the understanding. Consciousness is possible because the split between understanding and sensibility - i.e., critical difference - is conclusive. To cross this gap means to untie the knot of human consciousness. "Only after time was accomplished would the intelligence be wholly and completely freedom; but then it would be nothing. ${ }^{{ }^{36}}$ Freedom depends on the incompleteness of intelligence. But this is not, according to Fichte, a reason for skepticism or for the absence of an ultimate ground for knowing. Quite on the contrary. The issue is, mainly, to prove this very indemonstrability, and that leaves the WL in a unique situation. On the one hand, it shows the incompleteness of its own knowledge. On the other hand, as a consequence of that, it builds an image of itself and of its relation with its object, claiming a mediate realization of the so-called absolute which is at the basis of human knowing, albeit ambiguously and in oscillation. Showing that both the figurations of consciousness and the reflective selfconsciousness are not possible except on the basis of the image of an absolute being, the WL tries also to show, indirectly, and presupposing the fact of consciousness, the reference to the absolute as a necessary one.

Fichte thus keeps his first statement, that "we do not so much explain the explicandum as show rather, that, and why, it is inexplicable." ${ }^{37}$ The paradoxical and self-cancelling formulae converges into an interpretation of Fichte's WL as a self-referring and formally self-containing system of incompleteness. As we try to see the object of vision in itself, as we read in the WL of 1807, repeating the assertion in the Anweisung zum seligen Leben, "our own eye bars the way to our eye" ("unser Auge selbst steht unserm Auge im Wege"). ${ }^{38}$

\section{NOTES}

1. WL-1804-I, GA II/7, 144"Wir daher erscheinen uns, als blosse, zu vollziehende oder nicht vollziehende, in Absicht ihrer Wirklichkeit zwischen Seyn u. nichtseyn schwebende Aufgabe [...]." 2. Cf. WL-1804-I GA II/7, 192.

3. $\mathrm{KrV}, \mathrm{B} 131-132$.

4. WL-1805 GA II/9, 179: "wo gesprochen, wird von Etwas gesprochen, das in allen andren Fällen vor diesem Sprechen davon bekannt ist und da ist: - hier, von etwas, das nur durch das Sprechen davon, und in diesem Sprechen, ist und wird."

5. GWL, GA I/2, 409: "Das Ich muß [...] über sich reflektiren" (translation adapted from P. Heath and J. Lachs).

6. WL-1805, GA II/9, 215: "Das absolute \{innerlich\} (d.i zu seinem Seyn durchaus nichts voraussetzende als seine Seyn selber) Licht, sieht, notwendig sich: a/a."

7. WL-1801/2, GA II/6, 212.

8. Cf. ZE, GA I/4, 216-217.

9. GWL, GA I/2, 412: "derjenige Zirkel, den er [der endliche Geist] in das Unendliche erweitern, aus welchem er aber nie herausgehen kann." 
10. Cf. WUNDT, M., Fichte-Forschungen, Stuttgart: Frommann-Kurtz, 1929, p. 63.

11. GWL, GA I/2, 311: “[...] der Knoten [wird] nicht sowohl gelöst, als in die Unendlichkeit hinaus gesezt".

12. GWL, GA I/2, 311: “das zuerklärende nicht sowohl erklärt, als vielmehr gezeigt wird, daß, und warum es nicht zu erklären sey."

13. GWL, GA I/2, 367: "Wir sehen, daß gerade derjenige Umstand, welcher die Möglichkeit einer Theorie des menschlichen Wissens zu vernichten drohte, hier die einzige Bedingung wird, unter der wir eine solche Theorie aufstehen können".

14. GWL, GA I/2, 368.

15. GWL, GA I/2, 366.

16. GWL, GA I/2, 367.

17. GWL, GA I/2, 368.

18. Cf. GWL, GA I/2, 367.

19. Cf. GWL, GA I/2, 412-413.

20. GWL, GA I/2, 366-367: "wir hätten über sie nicht denken können, denn sie waren absolut Nichts, und über Nichts kann man nicht reflektiren."

21. GWL, GA I/2, 405“[S]oll [...] das Nicht-Ich überhaupt etwas im Ich setzen können, so muß die Bedingung der Möglichkeit eines solchen fremden Einflusses im Ich selbst, im absoluten Ich, vor aller wirklichen fremden Einwirkung vorher gegründet seyn; das Ich muß ursprünglich und schlechthin in sich die Möglichkeit setzen, daß etwas auf dasselbe einwirke; es muß sich, unbeschadet seines absoluten Setzens durch sich selbst, für ein anderes Setzen gleichsam offen erhalten."

22. WL-1801/02, GA II/6, 171.

23. WL-1801/02, GA II/6, 182"Der eigentliche Fokus, und Mittelpunkt des absoluten Wissens ist hiermit gefunden. Er liegt nicht im sich fassen als Wissen (vermittelst der formalen Freiheit) auch nicht im sich vernichten an dem absoluten Seyn, sondern schlechthin zwischen beiden; $u$. eines von beiden ist nicht möglich, ohne das zweite."

24. WL-1801/02, GA II/6, 182-183: "Es schwebt zwischen seinem Seyn, und seinem Nichtseyn: wie es wohl muß, da es seinem absoluten Ursprung wissend in sich trägt."

25. WL-1801/02, GA II/6, 171: "Das absolute Was des Wissens [...] als Was, unabhängig von aller Freiheit, [soll] sich finden [...]; für sich seyn. In diesem absoluten Was müsste es daher sich anschauen. Alle Anschauung aber ist Freiheit, schlechthin weil sie ist. Die Form dieser Anschauung wird sonach durch ihre Materie vernichtet, sie verschwindet schlechthin durch sich selbst in sich selbst."

26. Ibid.: "ein Wissen, ohne Selbstbewußtseyn."

27. About the transcendental function of the "question", see WL-1801/02, GA II/6, 174 and GWL, GA I/2, 403.

28. WL-1801/02, GA II/6, 182.

29. "Aber in der Anschauung ist, was in ihr ist, schlechthin weil es ist: mithin nicht mehr, schlechthin was es ist. Daher könnte diese Anschauung sich nicht anschauen, in keinem Wissen vorkommen, sondern sie vernichtete ihre Form schlechthin durch ihre Materie." (GA II/6, 182)

30. WL-1804-II, GA II/8, 182-183.

31. WL-1805, GA II/9, 182: "Der Satz: das Wissen an sich ist das, ist ohne Zweifel selbst wieder ein Wissen."

32. WL-1805, GA II/9, 291: "Die alten Metaphysiker haben daher sehr richtig die Form der höchsten, u. absoluten Einsicht gefaßt. Nur sie realisieren wollen, war ein misgriff. [...] Eine solche Einsicht ist in ihr selbst widersprechend; denn Einsicht sezt Objektivität der Glieder, noch dazu zweier; Gottes inneres Wesen aber ist Immanenz $u$, Einheit. [...] (Ferner, auf der Unmöglichkeit dieses Beweises beruht die Möglichkeit des Bewußtseyns." 
33. WL-1807, GA II/10, 171-172: “Er [sc. Gott] offenbart sich nur, als der nie zu offenbarende. [...] Könnte er jemals ganz, so wie er ist, eintreten in die Erscheinungen so wäre diese zu Ende. Nur daß sein unmittelbar niemals zu realisierender Trieb die Wurzel unsers scheinbaren Daseyns ist, bürgt uns für die Unendlichkeit dieses unser scheinbares Daseyn."

34. WL-1805, GA II/9, 257"das absolute verändert duch das Existiren sein eignes inneres Wesen absolute, unwiederbringlich."

35. Cf. WL-1807, GA II/10, 193.

36. WL-1801/02, GA II/6, 321: "Nur nach vollendeter Zeit wäre die Intelligenz ganz u. durchaus Freiheit; dann aber wäre sie nichts."

37. GWL, GA I/2, 311.

38. WL-1807, GA II/10, 112 .

\section{ABSTRACTS}

This paper studies cases of paradox and circular formulations from the Grundlage der gesamten Wissenschaftslehre of 1794/1795 until the Wissenschaftslehre of 1805. Such formulae are required to produce some of the main concepts of Fichte's thought, and allow us to draw both systematic and historical-conceptual conclusions about it. After a general presentation of the form and development of the WL, some examples of paradoxical or circular formulae are studied: As a conclusion it is shown why in the WL "we do not so much explain the explicandum as show, rather, that, and why, it is inexplicable." The paradox and circular formulae converge on an interpretation of Fichte's Science of Knowledge as a self-referent and self-contained system of incompleteness.

INDEX

Keywords: paradox, circular argument, incompleteness

\section{AUTHOR}

DIOGO FERRER

Coimbra 